\title{
Study of Local Revenue Sources In North Luwu Regency South Sulawesi Province-Indonesia
}

\author{
${ }^{1}$ Indrianty Sudirman, ${ }^{2}$ Mursalim Nohong, ${ }^{3}$ Muhammad Darwis, ${ }^{4}$ Muhammad Erik Kurniawan, ${ }^{5}$ Wahyu Hidayat, \\ ${ }^{6}$ Bambang Irawan, ${ }^{7}$ Rahmawati.
}

\author{
1,2,3,4,5Institute for Research and Community Service (LP2M) Hasanuddin University. Street Perintis Kemerdekaan KM. 10 Kampus Unhas Tamalanrea, \\ Makassar \\ 6,7Regional Research and Development Agency (BALITBANGDA) North Luwu District. Street Simpurusiang No. 27 Masamba.
}

Correspondence Author: Indrianty Sudirman, Institute for Research and Community Service (LP2M) Hasanuddin University. Street Perintis Kemerdekaan KM. 10 Kampus Unhas Tamalanrea, Makassar

Received date: 10 January 2018, Accepted date: 28 February 2018, Online date: 10 March 2018

Copyright: (c) 2018 Indrianty Sudirman et al. This is an open-access article distributed under the terms of the Creative Commons Attribution License, which permits unrestricted use, distribution, and reproduction in any medium, provided the original author and source are credited.

\begin{abstract}
The problems in this assessment are: (1) sources of revenue based on potentials that support locally generated revenue in the District of Luwu Utara; (2) strategies and policies for enhancing local revenue sources in Kabupaten Luwu Utara that can be professionally managed by local companies. The objectives of this assessment are to: (1) identify sources of revenue based on potentials that support locally generated revenue in the District of North Luwu ; (2) to formulate strategies and policies to increase local revenue sources in Kabupaten Luwu Utara that can be professionally managed by local companies. The study was conducted in North Luwu Regency South Sulawesi Province from April to July 2017. Data analysis using Analytical Hierarcy Process (AHP) and SWOT Analysis. The strategy is aimed at increasing revenue sources that can be managed by local companies in the industrial sector, plantation sector, livestock and fishery sector, tourism sector, renewable energy sector, and sand mining sector.
\end{abstract}

Key words: Regional revenue, local companies, economic sector, and locally generated revenue.

\section{INTRODUCTION}

Current national development covers all areas and certainly needs to get serious attention both from the government side in particular and society in general. The development itself can only be implemented if there is available funds. The funds can be obtained from various sources both from within and outside the country, both private and government sectors. According to the opinion of [1] One source of revenue from within the country is from the tax sector which is a form of community service and direct participation in order to succeed the national development, is also one form of government service to the community.

In an effort to support the implementation of national development, the government provides an opportunity to organize regional autonomy by issuing Law No. 23 of 2014 on Regional Government and Law No. 33 of 2004 on Financial Balance between the Central Government and Local Government. According to [2], regional autonomy is the authority of autonomous regions to regulate and manage the interests of local people according to their own initiative based on community aspirations in accordance with the laws and regulations. Regional authority includes the authority of the government, starting from the system of planning, financing, and implementation.

Law Number 33 Year 2004 regarding Financial Balance between the Central Government and Local Government indicates that in the framework of the implementation of regional autonomy, local governments are given the flexibility to manage and utilize local revenue sources that they have in accordance with the aspirations of local communities. To implement and implement broad, real, and responsible regional autonomy, local authorities and authorities are required to explore their own financial resources supported by the financial balance between the central government and local governments. Thus, local governments should be able to explore their own financial resources in order to perform their functions effectively and efficiently, namely in the areas of governance and service to the community.

In the context of carrying out regional autonomy, local governments should optimize the sources of regional revenue in the era of regional autonomy and fiscal decentralization. There is evidence, however, that the dramatic structural shift that occurred did not result in any appreciable and sustained economic growth and development [3]. Based on Law Number 33 Year 2004 regarding Fiscal Balance between Central Government and Local Government, the source of regional revenue consists of locally generated revenue, Fund of Balance; and other legitimate regional income.

In order to finance the development, the majority of district / municipality governments are still dependent on the Central Government through the Balancing Fund Allocation. As with the District of North Luwu with TA APBD Structure. 2017 consists of locally generated revenueof 7.8\%, Balancing Fund equal to $76.7 \%$ and Others Approximate Other Areas by $15.5 \%$. This shows that the dependence of the local government of North Luwu Regency is still very large to the Central Government, and the low level of regional autonomy in terms of fiscal capacity with the contribution of locally generated revenue in the regional income and expenditure budgets structure is only 7.8\%.From an economic point of view, the historicalism is certainly beneficial for the economic development in North Luwu along with the increasing mobility of the population and the opening of various business opportunities [4].

In addition to sourced from local taxes and levies, locally generated revenue can also be obtained from Separated Regional and Other Legal Resource Management Results. Locally generated revenue derived from the Separate Regional Property Management Result is income derived from the management of a local companies. Local companies has a role in realizing the prosperity of the region by contributing to the revenue of locally generated revenue in the form of dividends. The challenge of increasing locally generated revenue is one of them can be answered by increasing the role / contribution of local companies in carrying out its activities and the ability to absorb labor.

The purpose of this assessment is to identify sources of revenue based on the potential of supporting locally generated revenue in the District of Luwu Utara and to formulate strategies and policies to improve local revenue sources in Kabupaten Luwu Utara that can be professionally managed by local companies. Research Methods: 

of Local Revenue Sources In North Luwu Regency South Sulawesi Province-Indonesia. Advances in Environmental Biology., 12(2): 4-7.

This research was conducted in North Luwu Regency South Sulawesi Province in April until July 2017. Data collection was done by using two stages: First phase, survey activity to determine local revenue sources. This stage is carried out by observation as well as field observation of the existing conditions determine the sources of local revenue. In the second phase, first hand sources are conducted on various sources through Focus Group Discussion (FGD) activities, among others with related institutions / institutions, economic actors, community leaders and decision makers in the local government structure of Luwu Regency North at various levels. Interviews were conducted to find out the aspirations and needs of the community on potential sources of local revenue. Required information such as; functions and roles of each stakeholder in local revenue sources, the institutional form needed for local revenue sources, models and forms of cooperation between actors / actors in the management of local revenue sources, and policy design of resource management reception area. Then the data obtained were analyzed by using a set of analytical tools Hierarcy Process (AHP) and SWOT Analysis.

\section{RESULTS AND DISCUSSION}

\section{Identification of Resource Potential to be Manage Local Companies:}

1) Industry Sector:

The potential value of investment is very influential on the development of investment in the field of industry that can be managed by local companies. The workforce in the industrial sector according to the Office of Koperindag of North Luwu in 2015 is 5,847 people from 2,163 companies. Industry in North Luwu is dominated by Food, Beverage and Tobacco Industry sector by 55\% of total industrial sector in North Luwu [5]. Low investment value on business activity will result in low turnover. For more details can be seen in Table 1.

Table 1: Potential Value of Investment in Industry Field in Luwu Utara Regency

\begin{tabular}{lll}
\hline Industry Type & Owner's equity (Rp) & Turnover (Rp) \\
\hline Rattan furniture & 30.000 .000 & 80.000 .000 \\
\hline Wooden furniture & 20.000 .000 & 60.000 .000 \\
\hline Rice mill & 10.000 .000 & 30.000 .000 \\
\hline Coffee Mill & 10.000 .000 & 30.000 .000 \\
\hline Water tunnel & 1.000 .000 & 3.500 .000 \\
\hline Sewing & 2.000 .000 & 7.000 .000 \\
\hline Brick & 2.000 .000 & 7.000 .000 \\
\hline Welding workshop & 2.000 .000 & 5.000 .000 \\
\hline
\end{tabular}

Source: Dinas Koperasi dan UMKM Kabupaten Luwu Utara, 2016.

Table 1 explains that the investment value in the highest industry reaches Rp. 30.000.000, - for own capital, while the lowest investment value is in the type of culvert business is Rp.1.000.000, -. While the highest turnover reached Rp. 80.000.000, - for the type of rattan furniture industry. This explains that the potential value of investment in the field of industry is still open opportunities for business development that can be managed by local companies.

\section{2)Plantation Sector:}

Plantation crops cultivated and planted by farmers in North Luwu Regency are cocoa and oil palm with total commodity area of 2016 covering $38,127,60$ ha and 18,380,05 ha. In 2016, total cocoa production is 26,120.85 Ton and palm oil 335,288.55 Ton.

The decrease in planting area is not always followed by a decrease in production. This is because there are other factors affecting production level, such as the productivity of the land. The potential of the North Luwu plantation sector is very promising. Plantation commodities that can be cultivated are: cocoa, oil palm, coconut, hybrid coconut, coffee, patchouli, vanilla, sago, aren, nutmeg, pepper, areca nut, clove, and candlenut [6].

Of the various commodities there are some that can be cultivated by local companies, among others, cocoa commodity, palm oil commodity, commodities in coconut, coffee commodity, commodity palm, and sago commodity.

\section{3)Livestock and Fishery Sector:}

The types of cattle that are kept in Luwu Utara Regency are beef, pork and buffalo. The number of beef cattle in the year 2015 as many as 26,456 tails, an increase of 24,852 tails in 2014. Buffaloes and pigs also increased from 13,323 each and 32,499 in 2014 to 14,218 buffaloes and 32,749 pigs in 2015 .

The potential of livestock cultivated in Luwu Utara Regency consists of cows, buffalo, horses, goats and pigs [6]. The potential of livestock business processing can be started in the development of cultivation by utilizing the extent of land that can be used as a grazing field (ranch). In addition to cultivation, another business is fattening. The fattened livestock is subsequently cut, beef and buffalo are intended to meet the needs of the Luwu Utara region as well as out of the district. Buffaloes and pigs are marketed to Tana Toraja and Toraja Utara districts to meet the needs of traditional parties. Meat can be processed into several foodstuffs, such as meatballs, abon, sausage while the waste feces (feces) can be processed into compost and biogas.

Businesses that can be managed by local companies are slaughterhouses because until now the cutting efforts are still done by the community traditionally. Types of poultry that are kept in Luwu Utara Regency are chicken, laying chicken, and broiler. The population of chicken chickens increased compared to the year 2013 which is about 727.221 tail, increased to 838,062 in 2015. Chicken broilers, laying hens, and ducks have also increased since the year since 2013.

The development of freshwater fishery, especially mina paddy \& pond is found in all sub-districts within Luwu Utara Regency. Marine fisheries are only in Bone-Bone district, Tana Lili, Malangke and Malangke Barat. The relatively high production of fishery in Luwu Utara Regency is one of the business opportunity for local companies is the construction of cold storage.

\section{4)Tourism Sector:}

The district of Luwu Utara is an area full of elegance, which is omnipotent conferring natural beauty, landscapes, mountains, forests, beaches, seas and stunning cultural diversity. The splash of beauty and beauty makes the tourists will not saturate explore it. Tourism potential in North Luwu regency is still wide open. There are twelve sub-districts in Luwu Utara District that hold various tourism potentials, and have made improvements and open in welcoming domestic and foreign tourists.

Management of tourist objects can increase local revenue. Some business opportunities related to the tourism sector are the management of tourist objects as well as the establishment of lodging, hotels, and restaurants within the area / location of the tourist attraction [7].

\section{5)Renewable Energy Sector:}

Luwu Utara Regency is one of the areas in South Sulawesi Province that has renewable energy potential. Besides the natural resources of North Luwu Regency also has mineral and energy resources as well as other minerals. The potential of mineral resources is as described below: 1 . The presence of petroleum of 2.4 billion BOE, 2. Natural gas indicated in Pongko, 3. Iron Ore 317,451.91 ha (6,812 ha in exploration stage), 4. Primary gold and gold put in Rampi and Seko with content 0,9-9,0.ppm, 5. Quartz sand in Sabbang, Baebunta and Masamba, 6. Granite with 13,700,000,000 tons reserve in Sabbang, 7. Claystone in Sukamaju.

No less potential is North Luwu Regency, there is potential for river besides having the potential of C quarry mining in North Luwu has the potential to be developed as Hydroelectric Power Plant in Baliasse River (10 MW) and Micro Hydro Power Plant [8].

\section{6)Sand Mining Sector:}

River sediment potential other than as a natural wealth that can be utilized as well as a threat, because it can lead to flooding with the rise of water in some rivers, especially rivers that empties into the Gulf of Bone. 
Citation: Indrianty Sudirman, Mursalim Nohong, Muhammad Darwis, Muhammad Erik Kurniawan, Wahyu Hidayat, Bambang Irawan, Rahmawati., 2018. Study of Local Revenue Sources In North Luwu Regency South Sulawesi Province-Indonesia. Advances in Environmental Biology., 12(2): 4-7.

The evidence of the dependence of development on nature can be seen from the use of natural resources, especially sand mining which is one of the basic materials in building the building. Sand exploitation activities is one of the supporting sectors of the physical, economic and social development. The need for sand mining will continue to increase with the development of various physical facilities and infrastructure [8].

This opportunity can be captured by local companies in Luwu Utara Regency to manage the sand mining business which has enormous potential both in terms of volume and from the value of rupiah generated.From eleven rivers identified Rongkong River and River Baliase which has a large sand mining potential.

\section{Strategies and Policies for Increasing Local Revenue Sources in North Luwu Regency Professionally Managed by Local Companies:} 1)Industry Sector:

Industrial sector development and policy strategies are as follows: (a) Business in the industrial sector is developed by increasing the production and quality of industry; (b) Facilitating the acquisition and distribution of working capital for business actors in the industrial sector; (c) To stimulate the development of home industries providing instant kapurung raw materials; (d) Local companies manages and markets instant kapurung products; (e) Training of business actors in the industrial sector concerning the skill of producing instant kropung products; (f) Appeals to serve the instant Kapurung product produced by Local companies -built home industry as a dish at events performed by the district and private government; (g) Appeal to hotels, restaurants, culinary places, packaged food sales outlets and souvenirs to provide and sell instant kapurung; (h) The need for industrial estate aims to accommodate the activities of the processing and trading industries. The same opinion [9] adopt the strategic change to minimize the adverse effects of environmental and organizational factors on the relationship between entrepreneurial orientation and firm's performance.

\section{2)Plantation Sector:}

Development strategies and policies of the plantation sector are as follows: (a) Institutional strengthening of cocoa farming groups, oil palm and sago; (b) Enterprises in the plantation sector shall be developed by increasing the production and quality of the commodity; (c) Training and counseling of cocoa farming groups, palm oil, and sago on the cultivation, skill of producing processed products, and management and marketing aspects; (d) Building partnerships between local companies and cocoa farming groups, palm oil, and sago, marketing intermediaries and wholesalers. According to the opinion of [10] in addition to establishing a cooperative marketing association that acts as a coordination link that connects onion producers to export markets, and in the same time supervises collection and transport operations of the produced crop.

\section{3)Livestock and Fishery Sector:}

Development strategies and policies of livestock and fishery sectors as follows: (a) Improvement of livestock breeding management through integration of livestock with agriculture / plantation. According to the opinion of [11] the integration system of farming and livestock is suitable because mutually beneficial (symbiotic mutualism) with one another both in terms of supply of feed for buffalo and supply of manurefor agricultural crops. It can increase the income of farmers-breeders in North Toraja especially in Buntu pepasan District, in additiontheintegration process crop-livestock can significantly conserve nutrients from the soil; (b) Establishment and management of farmer groups to improve livestock productivity; (c) Development of home industry for processing of fishery products; (d) conducting promotional activities and publication of processed products of fishery products; (e) supervising, coaching / mentoring, and upgrading of skills and innovations, both for on farm business activities and the processing business activities of fishery products; (f) Increasing the quality of existing livestock and fishery products and having market prospects by granting patents and brands, and encouraging the creation of new processed products in the form of finished and semi-finished products; (g) Developing the pattern of livestock systems of core systems (local companies) - plasma (breeders), intermediary traders, and wholesalers; (h) Arrangement of mountainous areas into pastures; (i) Building an Animal Slaughterhouse (RPH) managed by local companies; (j) Building Cold Storage managed by local companies.

\section{4)Tourism Sector:}

Strategy of development and policy of tourism sector as follows: (a) Fruit planting in 3 (three) leading tourism object namely Bantimurung Nature Tourism, Nature Tourism Pincara and Nature Tourism Sarambu Alla; (b) Prevent the construction of settlements in the vicinity of the tourism object because it will reduce the natural level of natural attractions; (c) Management of natural attractions to the maximum and maintain the level of uniqueness owned; (d) Conducting promotion on the potential of natural attractions owned. The opinion of [12] it is promising that the Thai government has undertaken policies to attract mainland Chinese medical tourists. Understanding the requirements of potential medical tourists is vitally important for the development of medical tourism.; (e) Organizing cultural festivals on a regular basis; (f) Conduct promotion of tourist destinations to other areas; (g) Establish cultural arts groups in developing regional cultural arts; (h) Carry out cultural seminars; (i) The need for coordination between government and society; (j) Construction of road network, thus facilitating access to natural tourism areas; (k) Create tour packages in marketing; (1) Increasing public understanding of the importance of tourism sector development; (m) To build existing supporting facilities in the area of tourism object; (n) Incorporating historical attractions as curriculum of local history education in the territory of Luwu Utara Regency; (o) Take firm action against the people who commit illegal logging; (p) Reforestation to prevent possible natural disasters; (q) Establish working groups of craft arts; (r) Preserving cultural relics such as tombs that need to be maintained in authenticity.

\section{6)Renewable Energy Sector:}

Development strategy and policy of renewable energy sector as follows: (a) Planning of development and utilization of Micro Hydro Power Plant in supporting the development of economic potency; (b) To operate the Micro Hydro Power Plant properly in accordance with established procedures; (c) Increasing the condition of Micro Hydro Power Plant in supporting economic development; (d) Improving coordination relationship with provincial and central government in developing Micro Hydro Power Plant development plan; (e) Maintain, repair and replace damaged or distorted components; (f) To explore sources of funding for the development of Micro Hydro Power Plant outside the government; (h) Engaging in relationships and cooperation with third parties; (i) Enhancing the active role of the community in the effort to participate in maintaining / maintaining existing Micro Hydro Power Plant; (j) To formulate general policies and regulations with regard to electrical connections, fines, sanctions, rights and obligations; (k) Formulating financial policies such as electricity rates, financial management; (1) To formulate policies for the development of productive enterprises, community activities by utilizing Micro Hydro Power Plant that have been built.

\section{7)Sand Mining Sector:}

Development strategies and policies in the sand mining sector are as follows: (a) Strengthening the role of local companies; (b) Establishment of a sand distribution center / sand mining terminal at several strategic locations; (c) Localize trade through the Sand Terminal; (d) expansion of marketing area; (e) Implementing socialization and extension activities on environmental understanding of the communities in the watershed; (f) Carry out extension activities and plant management practices for erosion control; (g) Provision of technical assistance to sand mining business actors; (h) Provision of accessible and accurate sand mining information online; (i) Enhanced supervision and control functions; (j) Increased community engagement; (k) Build a partnership between local companies and sand mining business actors located in Luwu Utara Regency; (1) Improving the quality of road access; (m) Implement soil conservation and crop management activities for erosion control in watershed and coastal / downstream areas.

Conclusion:

Based on the analysis and discussion, it can be concluded as follows:

- Forms of business that can be managed by local companies are: (1) Industrial Sector is rice processing industry, instant kapurung industry and furniture industry; (2) Plantation sector is commodity of cocoa, oil palm, and sago as main ingredient of instant kapurung product, (3) Livestock and Fishery Sector are beef cattle, buffalo, broiler, shrimp, seaweed, milkfish and goldfish, (4) The Renewable Energy Sector is a Micro Hydro Power Plant, and (6) The Sector of Mining is a sand mining.

- Feasibility study of every business of Industrial, Plantation, Livestock and Fishery, Tourism, Renewable Energy and Mining sectors shall be managed 
by local companies.

\section{REFERENCES}

[1] Alimuddin and Wildan Syafitri, 2013. Regional Financial Planning Course Module and Budgeting. Director General of Regional Financial Balance. Jakarta.

[2] Law Number 23 of 2014 on Regional Government.

[3] Coster, A.S and M.I. Adekoya, 2010. Economic Impact of Unemployed Graduate Youths Training in Agricultural Activities in Ogun State. Research Journal of Social Sciences, 1(5): 87-95, 2010 ( ) 2010. Published by AENSI Publication.

[4] Sudirman, I., M. Aminawar, A.S. Alam, I.K. Sakharina, M. Darwis, M.E. Kurniawan, B. Irawan, R. Majid, 2017. Study of Security and Public Order Control Strategy in North Luwu Regency. International Journal of Scientific and Research Publications, 8(1): 2250-3153.

[5] Sudirman, I., M. Aminawar, A.S. Alam, I.K. Sakharina, M. Darwis, M.E. Kurniawan, B. Irawan, A.A. Paso. 2017. Strategy and Policy Development of Youth in North Luwu Regency. Journal of Law, Policy and Globalization, 69.

[6] Central Bureau of Statistics of Luwu Utara Regency, 2016. North Luwu in figures. Masamba (ID): BPS.

[7] Culture and Tourism Office of Luwu Utara Regency, 2017. Masamba.

[8] Environmental Office of Luwu Utara Regency, 2017. Masamba.

[9] Banila, R., 2017. Impact of Innovativeness on the Performance of Micro Industries. Journal of Applied Sciences Research. ISSN: 1819-544X. EISSN: 1816157X. (5)L 7-14. Published by AENSI Publication.

[10] Eman, A.A., A.A. Mohamed, 2017. Economic Analysis Of Agricultural Price Policy's Impact On Onion Crop Grown In Egypt. American-Eurasian Journal of Sustainable Agriculture. ISSN: 1995-0748, EISSN: 1998-1074 2017, 11(5): 35-41. Published by AENSIPublication.

[11] Suarda, A., M. Anshar, M. Darwis, Sudarsono, S. Hasan, Juhanis, 2017. The Characteristics of Integration System of Buffalo Cultivation in North Toraja Regency. American-Eurasian Journal of Sustainable Agriculture. ISSN: 1995-0748, EISSN: 1998-1074 2017, 11(1): 6-10. Published by AENSIPublication.

[12] Ye, H., I. Assenov, 2017. Mainland Chinese Tourists' Perception of Medical Tourism in Thailand. Research Journal of Social Sciences. ISSN: 1815-9125, EISSN: 2309-9631. 10(2): 8-13. Published by AENSIPublication. 